\title{
СОДЕРЖАНИЕ ЛИГНИНА И ЦЕЛЛЮЛОЗЫ В ОПАДЕ И ПОДСТИЛКЕ НЕНАРУШЕННЫХ И ПОДВЕРЖЕННЫХ ТЕХНОГЕННОМУ ЗАГРЯЗНЕНИЮ СЕВЕРОТАЕЖНЫХ СОСНОВЫХ ЛЕСОВ
}

\section{Артемкина Н.А.}

Институт проблем промышленной экологии Севера ФИЦ КНЦ РАН, Anamumbl, artemkina@inep.ksc.ru

Опад является важным, специфическим компонентом лесных экосистем. Разложение растительного опада является одним из основных процессов, регулирующих круговорот углерода и элементов питания и формирование органогенного горизонта в бореальных лесах [3]. Фенольные соединения играют немаловажную роль в почвенных процессах [5]. Отдельно следует выделить существенную роль лигнина - трёхмерного полимера фенольной природы. Будучи устойчивым к разложению компонентом, лигнин влияет на скорость разложения опада и, следовательно, затрагивает механизмы взаимодействия с организмами почвы и преобразования питательных веществ [4]. Содержание лигнина и целлюлозы в химическом составе лесного опада, прежде всего, зависит от разновидности растений, но и климатические, и экологические факторы также могут привести к значительным качественным и количественным изменениям в опаде и подстилке $[1,7]$.

Процесс деструкции растительного опада в бореальной зоне подразделяется на две основные стадии [4]:

1. Начальную стадию, когда на процесс разложения наибольшее влияние оказывают концентрация водорастворимых компонентов, содержание основных элементов питания и климатические условия.

2. $\quad$ Поздние стадии, когда определяющим темпы деструкции становится содержание лигнина. Согласно данным ранее проведенных исследований, загрязнение среды выбросами медепла-

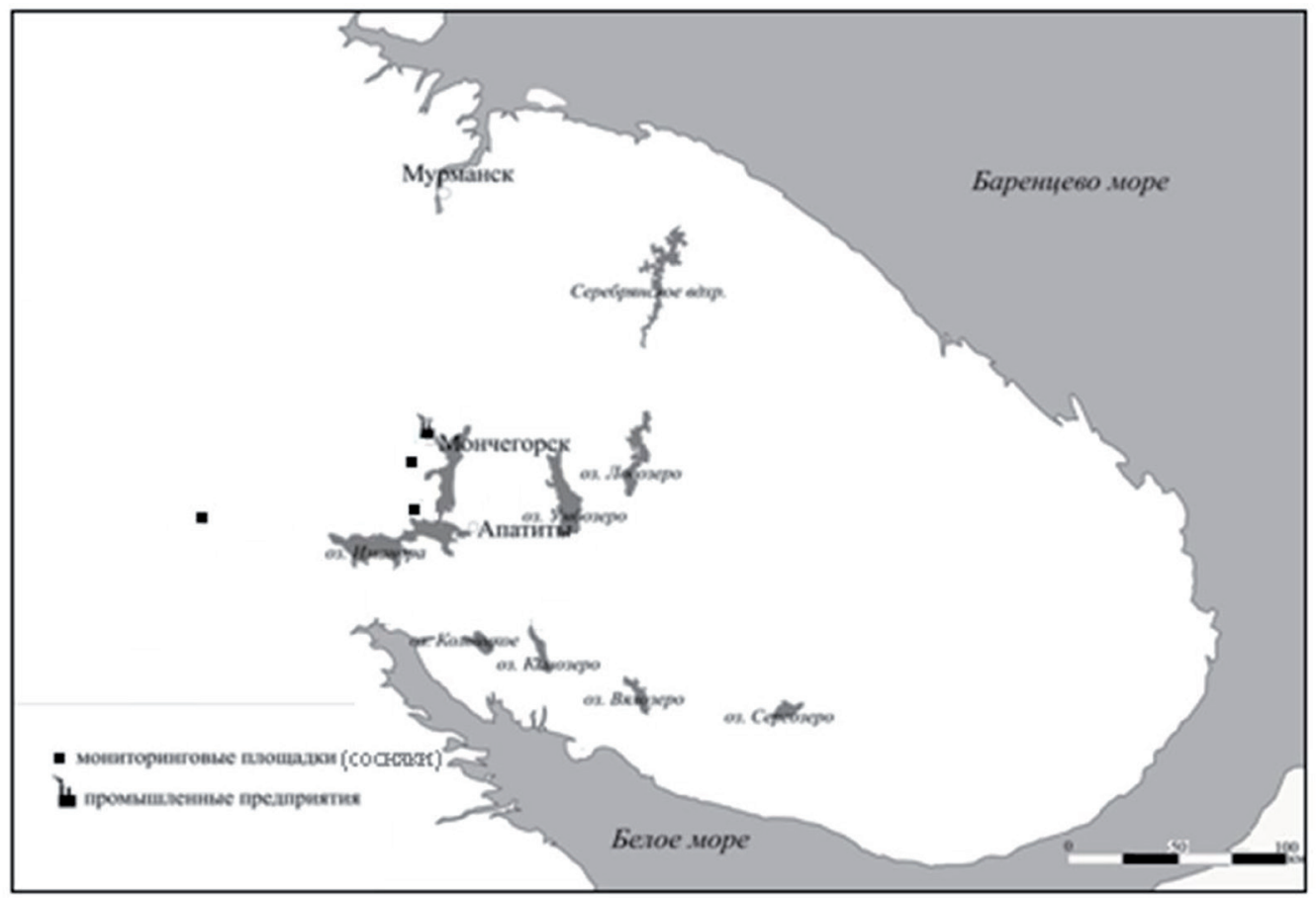

Рис. 1. Схема расположения площадок отбора проб. 
вильного завода в 3-5 раз уменьшает скорость деструкции чистой целлюлозы, резко увеличивая при этом ее пространственную вариабельность [2]. Кроме того установлено накопление лигнина в хвое Pinus sylvestris в условиях промышленного загрязнения [8].

Определение химического состава для различных видов растений может помочь в выявлении механизмов, управляющих скоростью разложения активного опада и подстилки в некоторых северных экосистемах (ненарушенных или подверженных техногенному загрязнению).

Наше исследование было направлено на определение концентраций лигнина и целлюлозы, а также показателя лигнин/целлюлоза в опаде и подстилке ненарушенных и подверженных техногенному загрязнению северотаежных сосновых лесов.

Исследования проводили в северотаежных лесах Кольского полуострова, подверженных и не подверженных промышленному воздушному загрязнению выбросами медно-никелевого комбината «Североникель». В частности в сосняках по градиенту загрязнения (на разных стадиях их техногенной трансформации) (рис. 1). Главная лесообразующая порода на выбранных площадках Pinus sylvestris L. Фоновые леса представлены сосняком кустарничково-зеленомошным (110 км от комбината). Леса, подверженные воздушному загрязнению, представлены дефолиирующими лесами (сосняк кустарничковый $(31$ км)) и сосновым редколесьем (10 км). Учитывая пространственную гетерогенность биогеоценозов, изучение проводили в их отдельных структурных частях - межкроновых парцеллах, отличающихся друг от друга составом, структурой, свойствами своих компонентов, спецификой их связей и материально-энергетического обмена.

В представленный период происходила существенная эмиссия тяжелых металлов комбинатом «Североникель». Эмиссия металлов в течение 1980-ых и 1990-ых составляла 3000-8000 тникеля и 1000-6000 тонн меди ежегодно [6]. Эксперимент продлился в течение 2 лет (с сентября 1997 до октября 1999 г.) с использованием пакетного метода. В пакеты из фильтроткани закладывали различные виды опада преобладающих сосудистых видов растений (Pinus sylvestris, Betula pubescens, Vaccinium vitis-idaea, Vaccinium myrtillus и Empetrum hermaphroditum) и образцы коричневых частей мхов (главным образом, Pleurozium schreberi), а также суммарную лесную подстилку. Пробы растительного материала (по 10 г каждая) помещали в межкроновые пространства в трех повторностях. Ежегодно в октябре отбирались пробы на анализ содержания основных компонентов.

В лаборатории образцы высушивали, затем каждый образец измельчали и просеивали через сито 1 мм. Содержание лигнина и целлюлозы определяли путем обработки пробы 72\%-ной серной кислотой, после предварительного кипячения в растворе цетилтриметиламмония бромида в $0.5 \mathrm{M} \mathrm{H}_{2} \mathrm{SO}_{4}$ [9].

\section{Динамика содержания лигнина}

По уровню исходного содержания лигнина в растительном опаде можно предложить следующий ряд для фоновых условий: кора сосны (47.9-55.3\%) > листья вороники (34.4-43.5\%) > подстилка (29.3-36.8\%) > древесина сосны (27.6-30.9\%) > листья берёзы (23.3-26.0\%) > хвоя сосны (18.2-21.4\%) > мхи (19.0\%) > листья черники (13.4-15.6\%)> листья брусники (12.6-15.4\%). При приближении к источнику загрязнения нашли накопление лигнина в исходных образцах листьев берёзы, вороники, подстилки и снижение его содержания в листьях брусники, черники, хвое сосны. Во мхах начальная концентрация остается неизменной. В древесине и коре сосны определённых тенденций в изменении количества лигнина в зависимости от интенсивности загрязнения не выявлено.

После прохождения двухгодичного деструкционного цикла максимальные концентрации лигнина характерны для всех видов опада, за исключением древесины, коры и хвои сосны, трансформирующихся на площадке около источника загрязнения. Количество лигнина в деструкционном цикле у древесины и коры сосны, листьев вороники, мхов и подстилки практически не изменяется. Значительное накопление лигнина для некоторых растений отмечено в первый год разложения опада за счет вымывания водорастворимых и легкогидролизуемых веществ, затем содержание лигнина относительно стабилизируется. Наибольшие концентрации лигнина за двухлетний период трансформации опада формируются в коре сосны и листьях брусники (49.1-56.0 и 50.5-56.2\%соответственно).Далееследуетрядубывания:листьячерники(50.5-56.2\%)>листьяберёзы 
(48.0-52.9\%) > листья вороники (41.6-50.5\%) > подстилка (30.8-40.6\%) > хвоя сосны (28.2-37.4\%) $>$ мхи $(18.2-23.5 \%)$.

\section{Динамика содержания целлюлозы}

По уровню исходного содержания целлюлозы в растительном опаде можно предложить следующий ряд для фоновых условий: древесина сосны (42.5-49.0\%) > мхи (28.2\%) > хвоя сосны $(24.3-26.0 \%)>$ кора сосны (19.4-23.4\%) > подстилка (14.4-18.7\%) > листья брусники (12.7-15.4\%) $>$ листья черники (11.6-13.1\%) > листья берёзы (12.5-13.7\%) > листья вороники (10.9-12.7\%). При приближении к источнику загрязнения нашли накопление целлюлозы в исходных образцах хвои и древесины сосны, листьев вороники, подстилки и снижение её содержания в коре сосны, листьях берёзы, брусники, черники. Во мхах начальная концентрация остается неизменной.

После прохождения двухгодичного деструкционного цикла максимальные концентрации целлюлозы характерны для древесины сосны, трансформирующейся на площадке около источника загрязнения, а также для Pleurozium schreberi в фоновых и дефолиирующих лесах. Количество целлюлозы в деструкционном цикле у коры сосны и подстилки достоверно не изменяется $(p>0.05)$. Значительное накопление целлюлозы для хвои ели, листьев берёзы, брусники, вороники и черники зафиксировано в первый год разложения опада за счет вымывания водорастворимых и легкогидролизуемых веществ, затем содержание целлюлозы уменьшается. Особенно ярко эта картина выраже-
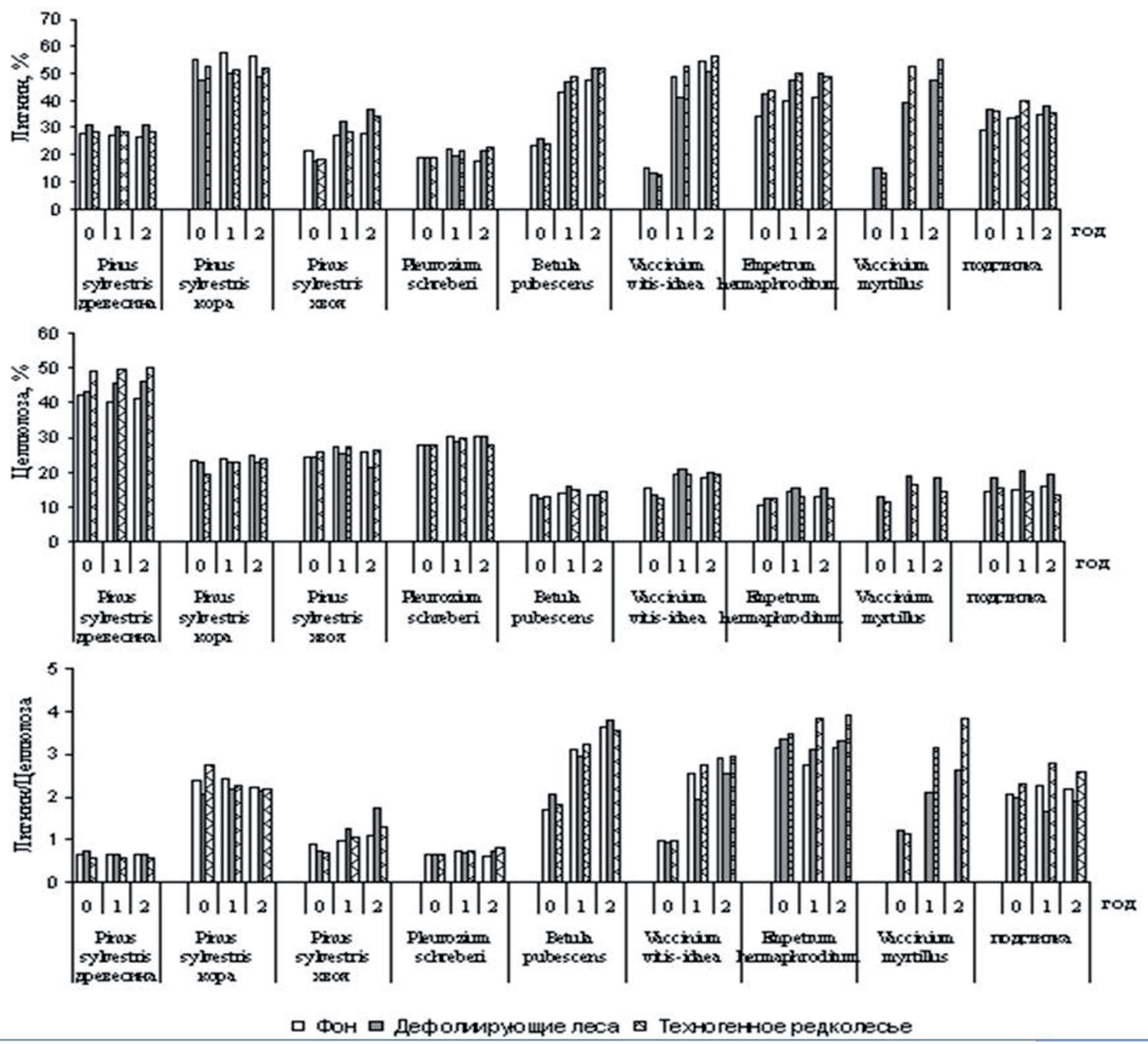

Рис. 2. Концентрации лигнина (\%) и целлюлозы (\%), показатель лигнин/целлюлоза. 
на на стадии дефолиирующих лесов.

По концентрации целлюлозы за двухлетний период трансформации опада можно сформировать следующий ряд: древесина сосны (41.3-50.0\%)> мхи (27.9-30.3\%) > хвоя сосны (21.5-26.5 \%)> кора сосны (22.9-25.1\%)> листья брусники (18.6-19.9\%) > листья черники (14.4-18.2\%) > подстилка (13.8-19.7\%)> листья берёзы (13.2-14.7\%)> листья вороники $(12.5-15.3 \%)$.

Показатель отношения лигнин/целлюлоза (в значительной степени определяет в дальнейшем скорость разложения опада в первой фазе) (рис. 2) уменьшается в порядке: листья вороники (2.8-3.9) $>$ листья берёзы (1.7-3.8) > листья черники (1.1-3.8) > листья брусники (1.0-3.0)> подстилка (1.7-2.8) $>$ кора сосны (2.0-2.7)> хвоя сосны (0.7-1.7)> мхи (0.6-0.8)> древесина сосны (0.6-0.7). С увеличением техногенной нагрузки происходит увеличение показателя лигнин/целлюлоза (начальное) в коре сосны, листьях вороники и в подстилке, в то же время показатель уменьшается в древесине и хвое сосны, листьях черники. Во мхах и листьях брусники начальная концентрация остается неизменной.

В ходе проведенного двухлетнего полевого эксперимента происходит стабилизация содержания лигнина на уровне 40-50\% за счет вымывания легкогидролизуемых веществ практически во всех видах опада, кроме древесины и коры сосны, содержание лигнина в которых не изменяется. При приближении к источнику загрязнения происходит накопление лигнина в разлагающемся опаде большинства исследованных видов. Концентрация целлюлозы накапливается в первый год трансформации опада, и только на второй год содержание целлюлозы начинает снижаться в большинстве видов опада (исключение составляют, как и в случае с лигнином древесина и кора сосны) на всех площадках различной степени загрязнения. Несмотря на то, что показатели лигнин/целлюлоза наименьшие у мхов и древесины сосны скорость потери массы у этих видов опада может быть ниже, чем у других видов, т.к. в этих случаях лигнин и другие малорастворимые фенольные соединения маскируют целлюлозу и делают её более стойкой к микробному разложению.

\section{Литература}

1. Артемкина Н.А., Лукина Н.В., Орлова М.А. Пространственное варьирование содержания вторичных метаболитов, углерода и азота в подстилках северотаежных ельников // Лесоведение. 2018. № 1. С. 37-47.

2. Воробейчик Е.Л., Пищулин П.Г. Влияние деревьев на скорость деструкции целлюлозы в почвах в условиях промышленного загрязнения // Почвоведение. 2011. № 5. С. 597-610.

3. Горбачева Т.Т., Лукина Н.В., Артемкина Н.А. Динамика содержания полифенолов при разложении опада и подстилки в ельниках зеленомошных Кольского полуострова // Лесоведение. 2006. № 3. С. 15-23.

4. Berg B. Foliar Litter Decomposition: A Conceptual Model with Focus on Pine (Pinus) Litter-A Genus with Global Distribution // ISRN Forestry. 2014. V. 2014. Article ID 838169. 22 pages.

5. Hättenschwiler S., Vitousek P.M. The role of polyphenols in terrestrial ecosystem nutrient cycling // Trends in Ecology and Evolution. 2000. V.15. № 6. P. 238-243.

6. Kozlov M.V., BarcanV. Environmental contamination in the central part of the Kola Peninsula: history, documentation, and perception // Ambio. 2000. V. 29. P. 512-517.

7. Lukina N.V., Orlova M.A., Steinnes E., Artemkina N.A., Gorbacheva T.T., Smirnov V.E., Belova E.A. Massloss rates from decomposition of plant residues in spruce forests near the northern tree line subject to strong air pollution // Environmental Science and Pollution Research. 2017. V. 24. N 24. P. 19874-19887.

8. Lukjanova A., Mandre M. Effects of Alkalization of the Environment on the Anatomy of Scots Pine (Pinus sylvestris) Needles // Water Air and Soil Pollution. 2010. V. 206. P. 13-22.

9. Rowland A.P., Roberts J.D. Lignin and cellulose fractionation in decomposition studies using acid-detergent fibre methods // Communications in Soil Science and Plant Analysis. 1994. V. 25. № 3-4. P. 269-277. 